\title{
A PHYSIOLOGICAL INVESTIGATION INTO THE INVASIVE BEHAVIOUR OF SOME PLANT SPECIES IN A MID - COUNTRY FOREST RESERVE IN SRI LANKA
}

\author{
W.A.J.M. DE COSTA*, H.M.G.S.B. HITINAYAKE and I.U. DHARMAWARDENA \\ Department of Crop Science, Faculty of Agriculture, University of Peradeniya, Peradeniya.
}

(Received: 06 July 2000 ; accepted: 17 October 2001)

\begin{abstract}
An introduced and naturalized plant species which increases its population excessively at the expense of other species in a given community is defined as an invasive species. The objective of this study was to determine whether some selected physiological characteristics were responsible for the invasive behaviour of eight plant species in the Udawattakelle forest reserve. These included saplings of three tree species, three shrub species and two herbaceous species. These were divided into three groups as early-successional, late-successional and gap species depending on their habitat within the forest. To compare the physiological measurements, ten noninvasive (i.e. 'standard') species were also selected. Results showed strong evidence that higher leaf net photosynthetic rates (Pn) under both high and low light conditions could be one of the factors responsible for the invasive behaviour of the latesuccessional species Myroxylon balsamum. Among the early successional and gap species, higher Pn under low light conditions could contribute to the invasive behaviour since it could give the invasive species a competitive advantage under the frequently cloudy conditions experienced in the Mid-Country Wet Zone in which Udawattakelle is located. A higher stomatal resistance $\left(R_{1}\right)$ was shown to be another factor contributing to the invasive behaviour in all successional groups because it would not only aid in the conservation of water during dry periods, but also give an advantage in the competition for water because of the higher water use efficiency at high $R_{1}$. In addition, a higher leaf nitrogen content, which is an indicator of higher photosynthetic capacity, was shown to be a factor contributing to the invasive behaviour in all successional groups. A higher leaf potassium content which helps to maintain cellular turgor under high transpiration rates, was shown to contribute to the invasive behaviour of early-successional and gap species which experience high solar irradiance levels, but not in late-successional species.
\end{abstract}

Key Words: Invasive species, leaf nitrogen content, leaf potassium content, Photosynthetic rate, stomatal resistance, Udawattakelle.

\section{INTRODUCTION}

A forest plant community is an ecosystem in which several plant species of different growth forms co-exist and interact in a dynamic system. Udawattakelle Forest Reserve is a semi-natural tropical wet, evergreen forest in the mid-country wet zone $\left(\mathrm{WM}_{3}\right)$. It contains about 460 plant species. Recent investigations by Senadheera ${ }^{1}$ and Hitinayake and Wedathanthri ${ }^{2}$ revealed that certain exotic plant species in Udawattakelle had a tendency of spreading rapidly over considerable areas of the forest. As a result, some patches of the forest were dominated by one plant species. 
Continuous spreading of these patches could significantly diminish the species diversity and threaten the overall biodiversity of this forest. The present study was undertaken to determine the physiological basis of this apparent invasive behaviour of eight plant species in Udawattakelle.

An invasive species can be defined as an introduced and naturalized plant species which increases its population density (i.e. the number of individuals per unit land area) excessively at the expense of other species in a given natural community or habitat. The population of a given species in a community can increase as compared to the other species due to several reasons. Firstly, an invasive species may produce more seeds than a non-invasive species so that it would have a greater number of germinated seedlings which could establish and grow further. Secondly, an invasive species may suffer less seedling death than the other species so that it would have a greater number of surviving seedlings which could grow further. The reduced seedling death could be due to the sudden elimination of a predator or amelioration of an environmental stress such as drought, salinity or nutrient shortage or toxicity. Thirdly, an invasive species may have greater ecological plasticity so that it may be able to establish and grow under a wide range of environmental (i.e. microclimatic and soil) conditions. This would mean that an invasive species could spread over a wide range of habitats of a given ecosystem whereas the non-invasive species would be confined only to those specific habitats that conform to their narrow ecological requirements. Fourthly, an invasive species may be able to use a limiting resource which is essential for plant growth (eg. light, water, nutrients etc.) more efficiently than the non-invasive species so that the invasive species are able to establish and grow faster at the expense of the non-invasive species.

The objective of the present study was to determine whether some selected physiological characteristics were responsible for the apparently invasive behaviour of several potential invasive plant species in the Udawattakelle forest reserve. The selected physiological characteristics were leaf photosynthetic rate under high and low light conditions, stomatal resistance, leaf nitrogen and potassium contents. These characters were selected by applying the basic principles of physiological plant ecology and they can be invoked to explain directly, the superior growth and survival of a given plant species in a community.

\section{METHODS AND MATERIALS}

Experimental location: The experiment was conducted at the Udawattakelle forest reserve in Kandy, Sri Lanka ( $7^{\circ} 15^{\prime} \mathrm{N}$ and $\left.80^{\circ} 45^{\prime} \mathrm{E}\right)$ from July to December 1999 . The site is located in the mid-country wet zone, $\mathrm{WM}_{3},{ }^{3}$ at an elevation of $500 \mathrm{~m}$ above mean sea level. The $75 \%$ expectancy of annual rainfall is around $1400 \mathrm{~mm}^{3}$. The $75 \%$ probability of monthly rainfall exceeds $100 \mathrm{~mm}$ during the 8 -month period from April to November. The 4-month period from December to March is relativelydry with the monthly $75 \%$ probability rainfall decreasing below $50 \mathrm{~mm}$ in January 
and February. ${ }^{3}$ The mean annual temperature is around $28^{\circ} \mathrm{C}$. Different patches of the forest contain Reddish Brown Latosol, Red Yellow Podzolic and Immature Brown Loam soils. ${ }^{3}$

The vegetation structure of Udawattakelle displays the typical canopy layers of a wet tropical rainforest. The most common tree species which form the canopy are Swietenia macrophylla (Mahogany), Michelia champaca (Gini-sapu) and Mesua ferrea $(\mathrm{Na})$. The sub-canopy is formed by tree species such as Filicium decipiens (Pihimbiya) and Euphoria longana (Mora). The forest floor has several plant species belonging to different growth- and plant forms including seedlings of trees and shrubs, herbaceous erect plants, vines and ferns. The forest contained areas of almost completely closed canopy cover as well as canopy gaps and open areas.

Species investigated: Based on the studies of Senadheera ${ }^{1}$ and Hitinayake and Wedathanthri, ${ }^{2}$ eight apparently invasive species, which included three tree species, three shrub species and two herbaceous species, were selected for this study (Tables 1-5). These were divided into three groups as early-successional species, late-successional species and gap species depending on their habitat and successional behaviour within the forest. In order to make quantitative comparisons of the physiological measurements, ten non-invasive (i.e. 'standard') plant species were also selected (Tables 1-5).

The difference between early-successional and gap species is the difference in environmental conditions that are experienced by their respective habitats. A gap species would grow in canopy gaps created within a well-established forest whereas early-successional species would grow on open sites. Unlike an open site, these canopy gaps experience direct solar radiation only during a limited part of the day., ${ }^{4,5}$ For a canopy gap on flat terrain, this would be around mid-day. At other times of the day, the gap would be partially-shaded by the surrounding canopy.

Five plants from each species investigated were selected and tagged for continuous measurements. Therefore, there was a total of 90 plants from 18 species. This high number of plants made it difficult to have a greater number of replicates per species. All plants selected were at the seedling or sapling stages. Within each species, plants at approximately similar growth stages were selected. The selected plants were subsequently used for measurement of nutrient contents.

\section{Measurements}

Leaf net photosynthetic rate $\left(P_{n}\right)$ : Leaf photosynthetic rate was measured in terms of the net $\mathrm{CO}_{2}$ exchange rate of fully-expanded top leaves of all species using a portable photosynthesis meter (LICOR6400, Nebraska, Lincoln, USA) via a closed system in the absolute mode. On each plant, $\mathrm{P}_{\mathrm{n}}$ of three replicate leaves were measured. From each plant species, three replicate plants were used for 
photosynthesis measurements. Measurements were done during the mid-day period between 1000 and 1400 hours on six separate days over a period of two months. Three of the measurement days were clear and sunny with high levels of solar irradiance. Hence, the net $\mathrm{CO}_{2}$ exchange measurements done on these days represented leaf net photosynthetic rates under saturating light conditions. The other three measurement days were cloudy with low levels of incoming solar radiation and hence provided photosynthetic rates under low light conditions.

Leaf diffusive resistance $\left(R_{\imath}\right)$ : Leaf diffusive resistance to water vapour transfer was measured using a Steady State Porometer (LICOR1600, Nebraska, Lincoln, USA) in the null-balance mode. Leaf diffusive resistance primarily measures the stomatal resistance. From each plant, $R_{1}$ of three fully-expanded top leaves were measured. Four replicate plants were sampled from each species. Intensity of photosynthetically-active radiation (PAR) on the leaf, instantaneous transpiration rate and leaf temperature were also measured along with $\mathrm{R}_{1}$. Measurements were done during the mid-day period between 1000 and 1400 hours on three separate days.

Leaf nutrient contents: Fully-expanded top leaves from five replicate plants of each species, including those used for $\mathrm{P}_{n}$ and $\mathrm{R}_{1}$ measurements, were harvested, ovendried and ground for nutrient analysis. Leaf nitrogen content was measured by the micro-Kjeldahl method. ${ }^{6}$ Leaf potassium content was measured by the dry ast method using the flame photometer. ${ }^{7}$

Data analysis: The objective of the statistical analysis was to test whether each of the measured physiological parameters differed significantly between invasive and non-invasive (i.e. standard) species within each successional group. Therefore, analyses of variance (ANOVA) were done separately for each species group. Least signifícant difference ${ }^{8}$ was used for mean separation within each species group.

In the case of photosynthesis and leaf diffusive resistance, data taken on different days of measurement were analyzed together with day of measurement included in the ANOVA table as a source of variation. Photosynthesis data taken on the three clear, sunny days and on the three cloudy days were analyzed separately.

\section{RESULTS AND DISCUSSION}

\section{Net photosynthetic rates under high $\left(\mathrm{P}_{n}{ }^{H}\right)$ and low $\left(\mathrm{P}_{n}^{L}\right)$ light conditions}

Separate analyses of variance of $\mathrm{P}_{n}{ }^{\mathrm{H}}$ and $\mathrm{P}_{n}{ }^{\mathrm{L}}$ showed that the respective values for the different species obtained on the three different days did not differ significantly $(p<0.05)$ between the days of measurement. Moreover, the interaction between days of measurement and species was not significant at $p=0.05$. Therefore, the data on 
the three different days of measurement could be pooled to obtain mean $\mathrm{P}_{n}{ }^{\mathrm{H}}$ and $\mathrm{P}_{\mathrm{n}} \mathrm{L}$ values for different species (Table 1).

Table 1 : Mean leaf net photosynthetic rates under saturating light levels, $\mathbf{P}_{\mathrm{n}}{ }^{\mathrm{H}}\left(\mu \mathrm{mol} \mathbf{m}^{-2} \mathbf{s}^{-1}\right)$, for plant species in different successional groups in Udawattakelle forest reserve.

\begin{tabular}{|c|c|c|c|c|c|}
\hline \multicolumn{2}{|c|}{ Late-successional species } & \multicolumn{2}{|c|}{ Early-successional species } & \multicolumn{2}{|c|}{ Gap species } \\
\hline Species & $\mathrm{P}_{\mathrm{n}}^{\mathrm{H}}$ & Species & $P_{n}^{H}$ & Species & $\mathrm{P}_{\mathrm{n}}^{\mathrm{H}}$ \\
\hline $\begin{array}{l}\text { Artocarpus } \\
\text { heterophyllus }\end{array}$ & $6.553 \mathrm{~A}$ & $\begin{array}{l}\text { Adenanthera } \\
\text { pavonina }\end{array}$ & $7.683 \mathrm{~A}$ & $\begin{array}{l}\text { *Jacobenia } \\
\text { coccinea }\end{array}$ & $6.454 \mathrm{~A}$ \\
\hline $\begin{array}{l}{ }^{*} \text { Myroxylon } \\
\text { balsamum }\end{array}$ & $6.317 \mathrm{~A}$ & $\begin{array}{l}\text { Cananga } \\
\text { odorata }\end{array}$ & $6.672 \mathrm{~B}$ & $\begin{array}{l}\text { Angiopteris } \\
\text { evecta }\end{array}$ & $5.335 \mathrm{~B}$ \\
\hline $\begin{array}{l}\text { Pterocarpus } \\
\text { indicus }\end{array}$ & $4.695 \mathrm{~B}$ & $\begin{array}{l}\text { * Castilla } \\
\text { elastica }\end{array}$ & $6.081 \mathrm{~B}$ & $\begin{array}{l}{ }^{*} \text { Costus } \\
\text { speciosus }\end{array}$ & $5.261 \mathrm{~B}$ \\
\hline Mesua ferrea & $4.417 \mathrm{~B}$ & $\begin{array}{l}\text { Alstonia } \\
\text { macrophylla }\end{array}$ & $3.296 \mathrm{C}$ & $\begin{array}{l}\text { "Swietenia } \\
\text { macrophylla }\end{array}$ & $3.759 \mathrm{C}$ \\
\hline $\begin{array}{l}\text { Artocarpus } \\
\text { nobilis }\end{array}$ & $2.455 \mathrm{C}$ & $\begin{array}{l}{ }^{*} \text { Scindapsus } \\
\text { aureus }\end{array}$ & $3.260 \mathrm{C}$ & $\begin{array}{l}\text { "Aglaonema } \\
\text { commutatum }\end{array}$ & $2.820 \mathrm{D}$ \\
\hline \multirow[t]{2}{*}{$\begin{array}{l}\text { Filicium } \\
\text { decipiens }\end{array}$} & $2.426 \mathrm{C}$ & $\begin{array}{l}\text { Terminalia } \\
\text { catappa }\end{array}$ & $2.460 \mathrm{D}$ & & \\
\hline & & $\begin{array}{l}\text { "Philodendron } \\
\text { scandens }\end{array}$ & $2.210 \mathrm{D}$ & & \\
\hline $\mathrm{LSD}_{0.05}$ & 0.819 & $\mathrm{LSD}_{0.05}$ & 0.734 & $\mathrm{LSD}_{0.05}$ & 0.814 \\
\hline $\mathrm{CV}(\%)$ & 22.43 & $\mathrm{CV}(\%)$ & 19.96 & $\mathrm{CV}(\%)$ & 23.96 \\
\hline
\end{tabular}

Note: Invasive species in each successional group are denoted by '”. Within each successional group, means having the same letter (i.e. $A, B, C$ ) are not significantly different at $p=0.05$

Table 1 shows that among the late-successional species, the invasive species, Myroxylon balsamum, had significantly $(\mathrm{p}<0.05)$ greater $\mathrm{P}_{\mathrm{n}}^{\mathrm{H}}$ values than all the non-invasive species except Artocarpus heterophyllus which had a $\mathrm{P}_{\mathrm{n}}{ }^{\mathrm{H}}$ value which was not significantly different from Myroxylon. A higher light-saturated photosynthetic rate would enable a species to achieve greater growth rates under high light intensities.9.10 Very often, the seedlings of late-successional species have to grow under low light levels found beneath the upper forest canopy. However, Pearcy ${ }^{11}$ and Chazdon ${ }^{12}$ have shown that a high proportion of carbon assimilation in such species occurs during brief periods of high sunlight (i.e. sunflecks) that reach the forest floor. Therefore, in the light climate experienced by the late-successional species, a high value of $\mathrm{P}_{n}$ under saturating light conditions could give the invasive 
species a competitive advantage over the other species in the same habitat. This could induce invasive behaviour.

Unlike in the late-successional species group, results of $\mathrm{P}_{\mathrm{n}}{ }^{\mathrm{H}}$ in the earlysuccessional group did not give a clear indication whether having a high $\mathrm{P}_{n}{ }^{\mathrm{H}}$ value could be responsible for their invasive behaviour (Table 1). However, among the three invasive species, the tree (i.e. Castilla) had a slightly higher $\mathrm{P}_{\mathrm{n}}{ }^{\mathrm{H}}$ value than the herbaceous plants. As compared to tree species, herbaceous species do not have a high proportion of non-productive woody tissue. Hence, it is most probable that the respiratory rates of herbaceous species would be lower than those of the tree species. ${ }^{13}$ Therefore, despite having lower photosynthetic rates, the two invasive herbaceous species in the early-successional group may have a greater net carbon balance than the non-invasive tree species, ${ }^{14}$ giving a competitive advantage to the invasive species over the non-invasive species.

Table 1 shows that within the gap species group, the invasive species Jacobenia coccinea had a significantly $(\mathrm{p}<0.05)$ greater $\mathrm{P}_{\mathrm{n}}{ }^{\mathrm{H}}$ value than the standard species Angiopteris evecta. Another invasive species Costus speciosus also had a $\mathrm{P}_{\mathrm{n}}{ }^{\mathrm{H}}$ value which was not significantly different from that of Angiopteris. On the other hand, the two invasive species Swietenia macrophylla and Aglaonema had significantly lower $\mathrm{P}_{\mathrm{n}}^{\mathrm{H}}$ values than the standard species.

Therefore, results on $\mathrm{P}_{n}{ }^{\mathrm{H}}$ do not give a clear indication that a high $\mathrm{P}_{\mathrm{n}}$ at high light intensities could contribute to the invasive behaviour of the gap species. However, it should be noted that in the early-successional and gap species groups, having a high $\mathrm{P}_{\mathrm{n}}$ value under high light conditions may not be the only factor responsible for the invasive behaviour. A wealth of experimental evidence has shown that pioneer species have greater light-saturated $\mathrm{P}_{\mathrm{n}}$ values than climax species. ${ }^{15,16}$ Therefore, in the early-successional and gap species groups, invasive species have to compete with non-invasive species most of which also have high $\mathrm{P}_{\mathrm{n}}{ }^{\mathrm{H}}$ values. Hence, other physiological or ecological parameters could be responsible for the invasive behaviour in these two groups.

Table 2 shows the mean rates of net $\mathrm{CO}_{2}$ exchange rates measured on cloudy days which represent comparative photosynthetic rates under low light conditions. Low light conditions are a frequent occurrence in tropical wet, evergreen forests located in high rainfall zones. Moreover, a certain number of non-rain days would also experience cloudy skies. Therefore, even the gap and early-successional species at Udawattakelle experience low incident radiation levels for a considerable period of the year. Therefore, species having high $\mathrm{P}_{\mathrm{n}}$ values under low light conditions could have a competitive advantage over the others and as a result could develop to be invasive. 
Table 2: Mean leaf net photosynthetic rates under low light levels, $P_{n}{ }^{L}$

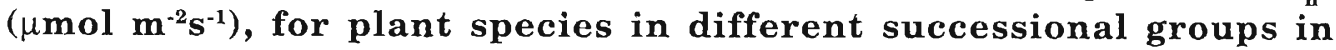
Udawattakelle forest reserve.

\begin{tabular}{|c|c|c|c|c|c|}
\hline \multicolumn{2}{|c|}{ Late-successional species } & \multicolumn{2}{|c|}{ Early-successional species } & \multicolumn{2}{|c|}{ Gap species } \\
\hline Species & $\mathrm{P}_{\mathrm{n}}^{\mathrm{L}}$ & Species & $P_{n}{ }^{L}$ & Species & $P_{n}{ }^{L}$ \\
\hline $\begin{array}{l}\text { *Myroxylon } \\
\text { balsamum }\end{array}$ & $5.183 \mathrm{~A}$ & $\begin{array}{l}{ }^{*} \text { Scindapsus } \\
\text { aureus }\end{array}$ & $9.413 \mathrm{~A}$ & $\begin{array}{l}{ }^{*} \text { Costus } \\
\text { speciosus }\end{array}$ & $5.838 \mathrm{~A}$ \\
\hline $\begin{array}{l}\text { Artocarpus } \\
\text { nobilis }\end{array}$ & $3.823 \mathrm{~B}$ & $\begin{array}{l}{ }^{*} \text { Philodendron } \\
\text { scandens }\end{array}$ & $3.118 \mathrm{~B}$ & $\begin{array}{l}{ }^{*} \text { Swietenia } \\
\text { macrophylla }\end{array}$ & $5.303 \mathrm{~A}$ \\
\hline Mesua ferrea & $2.509 \mathrm{C}$ & $\begin{array}{l}{ }^{*} \text { Castilla } \\
\text { elastica }\end{array}$ & $3.033 \mathrm{~B}$ & $\begin{array}{l}\text { Angiopteris } \\
\text { evecta }\end{array}$ & $4.746 \mathrm{~B}$ \\
\hline $\begin{array}{l}\text { Pterocarpus } \\
\text { indicus }\end{array}$ & $2.236 \mathrm{C}$ & $\begin{array}{l}\text { Adenanthera } \\
\text { pavonina }\end{array}$ & $2.391 \mathrm{C}$ & $\begin{array}{l}\text { * Jacobenia } \\
\text { coccinea }\end{array}$ & $3.828 \mathrm{C}$ \\
\hline $\begin{array}{l}\text { Filicium } \\
\text { decipiens }\end{array}$ & $1.785 \mathrm{C}$ & $\begin{array}{l}\text { Terminalia } \\
\text { catappa }\end{array}$ & $2.348 \mathrm{C}$ & $\begin{array}{l}\text { * Aglaonema } \\
\text { commutatum }\end{array}$ & $2.230 \mathrm{D}$ \\
\hline \multirow[t]{2}{*}{$\begin{array}{l}\text { Artocarpus } \\
\text { heterophyllus }\end{array}$} & $1.763 \mathrm{C}$ & $\begin{array}{l}\text { Alstonia } \\
\text { macrophylla }\end{array}$ & $2.324 \mathrm{C}$ & & \\
\hline & & $\begin{array}{l}\text { Cananga } \\
\text { odorata }\end{array}$ & $2.069 \mathrm{C}$ & & \\
\hline $\mathrm{LSD}_{0.05}$ & 1.200 & $\mathrm{LSD}_{0.05}$ & 0.634 & $\mathrm{LSD}_{0.05}$ & 0.545 \\
\hline $\mathrm{CV}(\%)$ & 21.04 & $\mathrm{CV}(\%)$ & 29.01 & $\mathrm{CV}(\%)$ & 22.23 \\
\hline
\end{tabular}

Note: Invasive species in each successional group are denoted by "*). Within each successional group, means having the same letter are not significantly different at $p=0.05$

Table 2 shows that among the late-successional group, the invasive species, Myroxylon, had significantly $(\mathrm{p}<0.05)$ greater $\mathrm{P}_{\mathrm{n}}^{\mathrm{L}}$ values than all the non-invasive late-successional species. As the seedlings of late-successional species grow mostly under low light conditions, having a high $\mathrm{P}_{\mathrm{n}}{ }^{\mathrm{L}}$ value would give Myroxylon a competitive advantage over the other species in the same habitat.

Earlier, it was shown that Myroxylon had a substantially high $\mathrm{P}_{\mathrm{n}}{ }^{\mathrm{H}}$ value as well (Table 1). Therefore, Myroxylon would be able to have high photosynthetic rates even during the periods when solar radiation penetrates down to the lower layers of the forest canopy at certain periods of the day. Consequently, the present study provides strong evidence that having high $\mathrm{P}_{n}$ values under both high and low light conditions could be a factor which is responsible for the invasive behaviour of Myroxylon. 
Table 2 shows that among the early-successional group, the three invasive species had significantly $(p<0.05)$ greater $\mathrm{P}_{n}{ }^{\mathrm{L}}$ values than all the non-invasive species. Table 2 also.shows that among the gap species, the two invasive species Swietenia macrophylla and Costus speciosus had significantly greater $\mathrm{P}_{\mathrm{n}}{ }^{\mathrm{L}}$ values than the standard Angiopteris. Especially, it can be noted that Swietenia, which had a comparatively lower $\mathrm{P}_{\mathrm{n}}$ under high light conditions (Table 1 ), had a high $\mathrm{P}_{\mathrm{n}}$ under low light conditions. This should help Swietenia to survive and establish under low light conditions.

The herbaceous invasive species Aglaonema has shown comparatively lower $\mathrm{P}_{n}$ values under both high and low light conditions (Tables 1 and 2). As mentioned earlier, Aglaonema, being a herbaceous plant, probably does not have high respiration rates. Hence, the comparatively lower photosynthesis rates may be enough to have a greater net carbon balance needed to be competitive over the other herbaceous species and seedlings of tree species in this habitat.

\section{Leaf diffusive resistance $\left(R_{1}\right)$}

Leaf diffusive resistance primarily measures the resistance of the stomata to transfer of gases such as water vapour and carbon dioxide between the leaves and the surrounding environment. A high value of $R_{1}$ helps a plant to conserve water by having lower transpiration rates and thereby survive periods of water shortage. Therefore, a species having a greater population within a given community (i.e. an invasive species as defined earlier) could have a higher $R_{1}$ value than the non-invasive species in the same community or habitat.

Because of the absence of significant effects or interactions involving different days of measurement, $R_{1}$ values obtained on the three different days were pooled to obtain mean values for each species. Table 3 shows that in the late-successional group, $\mathrm{R}_{1}$ of the invasive species, Myroxylon, was higher than all the species except Artocarpus heterophyllus. Therefore, in addition to its photosynthetic characteristics (i.e. high photosynthetic rates under both saturating- and low light levels), the higher stomatal resistance could also have contributed to the invasiveness of Myroxylon.

Table 3 shows that among the early-successional group, two of its invasive species, namely Philodendron scandens and Scindapsus aureus had significantly greater $R_{1}$ than the rest of the species in the group. However, the other invasive species Castilla had the lowest $\mathrm{R}_{1}$ in this group. As Castilla is a tree species, it is most probable that its root system is deeper than those of Philodendron and Scindapsus which are herbaceous plants. Therefore, Castilla would be able to keep its stomata open to a greater degree as it could tolerate a greater transpirational water loss. This is because Castilla would have a greater water supply tirough its deeper root system. 
Among the gap species group, all the species identified as invasive had higher $\mathrm{R}_{1}$ values than the standard Angiopteris (Table 3). The $\mathrm{R}_{1}$ values of Aglaonema and Swietenia macrophylla were significantly $(\mathrm{p}<0.05)$ greater than the standard whereas the others were not. This absence of statistical significance in $\mathrm{R}_{1}$ of Jacobenia and Costus could have been because of the higher variability of this data set as indicated by the higher coefficient of variation (Table 3 ).

Table 3 : Mean leaf diffusive resistance $R_{1}\left(\mathrm{~s} \mathrm{~cm}^{-1}\right)$, for plant species in different successional groups in Udawattakelle forest reserve.

\begin{tabular}{|c|c|c|c|c|c|}
\hline \multicolumn{2}{|c|}{ Late-successional species } & \multicolumn{2}{|c|}{ Early-successional species } & \multicolumn{2}{|c|}{ Gap species } \\
\hline Species & $\mathrm{R}_{1}$ & Species & $\mathrm{R}_{1}$ & Species & $\mathrm{R}_{1}$ \\
\hline $\begin{array}{l}\text { Artocarpus } \\
\text { heterophyllus }\end{array}$ & $6.475 \mathrm{~A}$ & $\begin{array}{l}{ }^{*} \text { Philodendron } \\
\text { scandens }\end{array}$ & $15.50 \mathrm{~A}$ & $\begin{array}{l}\text { *Aglaonema } \\
\text { commutatum }\end{array}$ & $7.852 \mathrm{~A}$ \\
\hline $\begin{array}{l}\text { "Myroxylon } \\
\text { balsamum }\end{array}$ & $5.835 \mathrm{~A}$ & $\begin{array}{l}\text { * Scindapsus } \\
\text { aureus }\end{array}$ & $7.687 \mathrm{~B}$ & $\begin{array}{l}\text { * Swietenia } \\
\text { macrophylla }\end{array}$ & $5.265 \mathrm{~B}$ \\
\hline Mesua ferrea & $5.687 \mathrm{~B}$ & $\begin{array}{l}\text { Alstonia } \\
\text { macrophylla }\end{array}$ & $5.337 \mathrm{C}$ & $\begin{array}{l}\text { *Jacobenia } \\
\text { coccinea }\end{array}$ & $3.023 \mathrm{C}$ \\
\hline $\begin{array}{l}\text { Artocarpus } \\
\text { nobilis }\end{array}$ & $3.072 \mathrm{C}$ & $\begin{array}{l}\text { Adenanthera } \\
\text { pavonina }\end{array}$ & $4.195 \mathrm{D}$ & $\begin{array}{l}{ }^{*} \text { Costus } \\
\text { speciosus }\end{array}$ & $2.993 \mathrm{D}$ \\
\hline $\begin{array}{l}\text { Filicium } \\
\text { decipiens }\end{array}$ & $2.088 \mathrm{D}$ & $\begin{array}{l}\text { Cananga } \\
\text { odorata }\end{array}$ & $3.248 \mathrm{D}$ & $\begin{array}{l}\text { Angiopteris } \\
\text { evecta }\end{array}$ & $2.805 \mathrm{C}$ \\
\hline \multirow[t]{2}{*}{$\begin{array}{l}\text { Pterocarpus } \\
\text { indicus }\end{array}$} & $1.538 \mathrm{E}$ & $\begin{array}{l}\text { Terminalia } \\
\text { catappa }\end{array}$ & $2.233 \mathrm{E}$ & & \\
\hline & & $\begin{array}{l}{ }^{*} \text { Castilla } \\
\text { elastica }\end{array}$ & $1.653 \mathrm{E}$ & & \\
\hline $\mathrm{LSD}_{0.05}$ & 0.541 & $\mathrm{LSD}_{0.05}$ & 0.964 & $\mathrm{LSD}_{0.05}$ & 0.814 \\
\hline $\mathrm{CV}(\%)$ & 23.87 & $\mathrm{CV}(\%)$ & 26.89 & $\mathrm{CV}(\%)$ & 32.23 \\
\hline
\end{tabular}

Note: Invasive species in each successional group are denoted by '“’. Within each successional group, means having the same letter are not significantly different at $\mathrm{p}=0.05$

The overall summary on the $R_{1}$ data show that in most of the invasive species of all successional groups, a high $R_{1}$ contributed to their invasive behaviour. It is notable that Aglaonema which had lower $\mathrm{P}_{\mathrm{n}}$ values under both higher and lower light conditions, had the highest $\mathrm{R}_{1}$ among the gap species group indicating that the higher stomatal resistance could be responsible for its invasive behaviour.

A high stomatal resistance, while decreasing the loss of water through transpiration, could also reduce the uptake of $\mathrm{CO}_{2}$ and thereby reduce the 
photosynthetic rate.${ }^{17}$ However, it has been shown that as compared to transpiration, photosynthesis is less affected by increases in stomatal resistance. ${ }^{18,19}$ This is because plants are able to adjust their internal $\mathrm{CO}_{2}$ concentration to maintain $\mathrm{CO}_{2}$ uptake despite having higher stomatal resistances. ${ }^{20}$ Therefore, the water use efficiency of the plant (i.e. the amount of dry matter produced through photosynthesis per unit of water lost through transpiration) is usually increased when the stomatal resistance is increased. ${ }^{18}$ Having a higher water use efficiency (WUE) would enable a plant to have a higher rate of biomass production with a lower amount of water loss. ${ }^{10}$ Hence, in addition to being able to survive periods of water shortage, plant species with high WUE would be able to tolerate high levels of inter-plant competition for water. ${ }^{21}$ Hence, a high stomatal resistance and thereby a high WUE, could contribute significantly to the invasiveness of a species. ${ }^{16}$

\section{Leaf nitrogen content (LN)}

Physiological studies on a wide range of plant species have shown clearly that leaf nitrogen content (LN) is highly correlated with the photosynthetic capacity of both cultivated and wild plant species. ${ }^{22,23}$ Nitrogen is an essential component of proteins. As all enzymes are proteins, a higher LN indicates a higher concentration of enzymes in leaf tissue. It has been found that the primary photosynthetic enzyme, Ribulose1,6 bis-Phosphate Carboxylase-Oxygenase (Rubisco) accounts for around $25 \%$ of leaf $\mathrm{N}^{24}$ and up to $50 \%$ of soluble leaf protein. ${ }^{25}$ Therefore, a higher $\mathrm{LN}$ indicates a higher concentration of Rubisco in leaf tissue which in turn indicates a higher photosynthetic capacity ${ }^{22,23}$ As discussed earlier in the section on photosynthesis, a plant species with a higher photosynthetic capacity would be able to grow faster than the other species in the same community or habitat. Therefore, such a species could develop into an invasive species.

Table 4 shows that among the late-successional group, the invasive species, Myroxylon, has a significantly $(\mathrm{p}<0.05)$ greater $\mathrm{LN}$ than all species in this group except Pterocarpus. Among the early-successional group, the three invasive species Philodendron, Castilla and Scindapsus had greater LN than all the non-invasive species in this group except Adenanthera pavonina which is a legume (Table 4). The probable reason for the high LN of Adenanthera is its capability of fixing atmospheric nitrogen. Two of the early-successional invasive species (i.e. Scindapsus and Philodendron) are herbaceous species. As explained earlier, these herbaceous species would not need a very high LN level and very high photosynthetic capacities to have a high carbon balance because of their lower respiration rates. Table 4 shows that among the gap species, all invasive species in this group except Swietenia macrophylla have significantly greater LN than the standard species Angiopteris which is the only fern in this group.

Results of Table 4 provide evidence that in all successional groups of species, a higher LN could be one of the factors responsible for the invasive behaviour of a 
given plant species. However, there could be exceptions such as Swietenia macrophylla which did not have a high LN (Table 4). In the earlier sections, it was identified that Swietenia had a higher net photosynthetic rate under low light conditions (Table 2). Under such conditions, maximizing light capture by having a higher leaf chlorophyll content is comparatively more important than having a high leaf $\mathrm{N}$ content to maximize carboxylation in the Calvin cycle. ${ }^{26} \mathrm{Hence}$, in the case of Swietenia, LN is probably not the reason for its invasive behaviour.

Table 4: Leaf nitrogen $\mathrm{LN}(\%)$, for plant species in different successional groups in Udawattakelle forest reserve.

\begin{tabular}{|c|c|c|c|c|c|}
\hline \multicolumn{2}{|c|}{$\begin{array}{l}\text { Late-successional species } \\
\text {. }\end{array}$} & \multicolumn{2}{|c|}{ Early-successional species } & \multicolumn{2}{|c|}{ Gap species } \\
\hline Species & $\mathrm{LN}$ & Species & $\mathrm{LN}$ & Species & $\mathrm{LN}$ \\
\hline $\begin{array}{l}\text { Pterocarpus } \\
\text { indicus }\end{array}$ & $4.003 \mathrm{~A}$ & $\begin{array}{l}\text { Adenanthera } \\
\text { pavonina }\end{array}$ & $4.446 \mathrm{~A}$ & $\begin{array}{l}\text { * Jacobenia } \\
\text { coccinea }\end{array}$ & $5.005 \mathrm{~A}$ \\
\hline $\begin{array}{l}\text { "Myroxylon } \\
\text { balsamum }\end{array}$ & $2.537 \mathrm{~A}$ & $\begin{array}{l}\text { "Philodendron } \\
\text { scandens }\end{array}$ & $2.541 \mathrm{~B}$ & $\begin{array}{l}{ }^{*} \text { Costus } \\
\text { speciosus }\end{array}$ & $2.680 \mathrm{~B}$ \\
\hline $\begin{array}{l}\text { Artocarpus } \\
\text { nobilis }\end{array}$ & $2.115 \mathrm{~B}$ & $\begin{array}{l}\text { * Castilla } \\
\text { elastica }\end{array}$ & $2.430 \mathrm{BC}$ & $\begin{array}{l}\text { *Aglaonema } \\
\text { commutatum }\end{array}$ & $2.614 \mathrm{~B}$ \\
\hline $\begin{array}{l}\text { Artocarpus } \\
\text { heterophyllus }\end{array}$ & $2.060 \mathrm{C}$ & $\begin{array}{l}{ }^{*} \text { Scindapsus } \\
\text { aureus }\end{array}$ & $2.177 \mathrm{CD}$ & $\begin{array}{l}\text { Angiopteris } \\
\text { evecta }\end{array}$ & $2.299 \mathrm{D}$ \\
\hline $\begin{array}{l}\text { Filicium } \\
\text { decipiens }\end{array}$ & $1.760 \mathrm{D}$ & $\begin{array}{l}\text { Cananga } \\
\text { odorata }\end{array}$ & $2.093 \mathrm{D}$ & $\begin{array}{l}\text { * Swietenia } \\
\text { macrophylla }\end{array}$ & $1.838 \mathrm{D}$ \\
\hline \multirow[t]{2}{*}{ Mesua ferrea } & $1.363 \mathrm{E}$ & $\begin{array}{l}\text { Terminalia } \\
\text { catappa }\end{array}$ & $2.033 \mathrm{D}$ & & \\
\hline & & $\begin{array}{l}\text { Alstonia } \\
\text { macrophylla }\end{array}$ & $1.754 \mathrm{E}$ & & \\
\hline $\mathrm{LSD}_{0.05}$ & 0.179 & $\mathrm{LSD}_{0.05}$ & 0.270 & $\operatorname{LSD}_{0.05}$ & 0.223 \\
\hline $\mathrm{CV}(\%)$ & 5.88 & CV(\%) & 8.28 & $\mathrm{CV}(\%)$ & 5.75 \\
\hline
\end{tabular}

Note: Invasive species in each successional group are denoted by i*. Within each successional group, means having the same letter are not significantly different at $p=0.05$

\section{Leaf potassium content (LK)}

Potassium has several important functions in plant cells. These include activating enzymes in key physiological processes such as protein synthesis, glycolysis and photosynthesis ${ }^{27-30}$ and providing the correct ionic environment in the cytoplasm so that physiological and metabolic processes can take place at their optimum rates. ${ }^{31}$ Moreover, $\mathrm{K}$ is a major contributor to the cellular osmotic potential and thereby 
helps to maintain cellular turgor pressure ${ }^{32-33}$ Maintainance of optimum cell turgor and water relations would allow the key physiological processes to function at their maximum capacity. ${ }^{31}$

Because of the importance of $\mathrm{K}$ in internal plant functioning, a species with a higher leaf $\mathrm{K}$ content (LK) may have a competitive advantage over the other species in the community and thereby could contribute to the invasive behaviour in some plant species. Table 5 shows that the invasive species, Myroxylon, has an intermediate level of LK within the late-successional species group. Myroxylon had a significantly $(p<0.05)$ greater LK than two of the non-invasive climax species (i.e. Filicium and Mesua). However, three of the non-invasive climax species had significantly greater LK than Myroxylon. Therefore, these results do not show conclusive evidence that a higher LK is a factor contributing to the invasive behaviour of Myroxylon.

Two of the invasive species (Scindapsus and Philodendron) among the earlysuccessional group had significantly $(\mathrm{p}<0.05)$ greater LK than the rest in the group (Table 5). The third invasive species, Castilla, also had a significantly greater $\mathbb{L K}$ than all the non-invasive species in the group except Cananga. Therefore, Table 5 shows evidence that in contrast to the late-successional species, a higher LK could be a factor contributing to the invasive behaviour among the early-successional species. This is probably because the early-successional species experience high solar radiation levels which would induce higher transpiration rates. Hence, the ability to maintain cellular turgor and optimum plant water relations, would be a key requirement for these species to succeed. Hence, a pioneer species having a high $\mathbb{L K K}$ level would have a competitive advantage over the other pioneers.

In contrast, the late-successional species do not experience high radiation levels for most of the day and are not subjected to high transpiration rates. Therefore, maintaining cellular turgor and optimum plant water relations is not a critical requirement in these species. This probably explains why a higher LK is not an important factor contributing to the invasive behaviour among the late-successional species. Table 5 also shows that all invasive species in the early-successional group had higher LK values than Myroxylon which was the invasive species in the late-successional group.

Among the three invasive species in the pioneer group, the slightly lower LK of Castilla could also be explained in terms of its water relations. Castilla is a tree species while the other two (i.e. Scindapsus and Philodendron) are herbaceous species. Maintaining cellular turgor is more critical to herbaceous species than to tree species which have deeper root systems and therefore are able to sustain greater transpiration losses than the herbaceous species. Hence having a higher leaf $\mathrm{K}$ content is more essential to herbaceous invasive species than to tree species. 
Table 5 : Leaf potassium LK (mg of $\mathrm{K} / 100 \mathrm{~g}$ of leaf dry matter), for plant species in different successional groups in Udawattakelle forest reserve.

\begin{tabular}{|c|c|c|c|c|c|}
\hline \multicolumn{2}{|c|}{ Late-successional species } & \multicolumn{2}{|c|}{ Early-successional species } & \multicolumn{2}{|c|}{ Gap species } \\
\hline Species & LK & Species & LK & Species & LK \\
\hline $\begin{array}{l}\text { Pterocarpus } \\
\text { indicus }\end{array}$ & $346.2 \mathrm{~A}$ & $\begin{array}{l}\text { * Scindapsus } \\
\text { aureus }\end{array}$ & $648.0 \mathrm{~A}$ & $\begin{array}{l}{ }^{*} \text { Aglaonema } \\
\text { commutatum }\end{array}$ & $531.6 \mathrm{~A}$ \\
\hline $\begin{array}{l}{ }^{*} \text { Artocarpus } \\
\text { heterophyllus }\end{array}$ & $345.2 \mathrm{~A}$ & $\begin{array}{l}\text { "Philodendror } \\
\text { scandens }\end{array}$ & $476.4 \mathrm{~B}$ & $\begin{array}{l}\text { * Jacobenia } \\
\text { coccinea }\end{array}$ & $425.0 \mathrm{~A}$ \\
\hline $\begin{array}{l}\text { Artocarpus } \\
\text { nobilis }\end{array}$ & $302.0 \mathrm{~B}$ & $\begin{array}{l}\text { Cananga } \\
\text { odorata }\end{array}$ & $466.2 \mathrm{~B}$ & $\begin{array}{l}{ }^{*} \text { Costus } \\
\text { speciosus }\end{array}$ & $404.6 \mathrm{~B}$ \\
\hline $\begin{array}{l}\text { "Myroxylon } \\
\text { balsamum }\end{array}$ & $246.0 \mathrm{C}$ & $\begin{array}{l}\text { Castilla } \\
\text { elastica }\end{array}$ & $358.2 \mathrm{C}$ & $\begin{array}{l}\text { Angiopteris } \\
\text { evecta. }\end{array}$ & $348.6 \mathrm{C}$ \\
\hline $\begin{array}{l}\text { Filicium } \\
\text { decipiens }\end{array}$ & $200.2 \mathrm{D}$ & $\begin{array}{l}\text { Terminalia } \\
\text { odorata }\end{array}$ & $328.2 \mathrm{D}$ & $\begin{array}{l}\text { Swietenia } \\
\text { macrophylla }\end{array}$ & $255.0 \mathrm{D}$ \\
\hline \multirow[t]{2}{*}{ Mesua ferrea } & $111.0 \mathrm{E}$ & $\begin{array}{l}\text { Alstonia } \\
\text { macrophylla }\end{array}$ & $310.0 \mathrm{D}$ & & \\
\hline & & $\begin{array}{l}\text { Adenanthera } \\
\text { pavonina }\end{array}$ & $238.4 \mathrm{E}$ & & \\
\hline $\mathrm{LSD}_{0.05}$ & 15.38 & $\mathrm{LSD}_{0.05}$ & 25.90 & $\operatorname{LSD}_{0.05}$ & 43.80 \\
\hline CV(\%) & 4.51 & $\mathrm{CV}(\%)$ & 4.92 & $\mathrm{CV}(\%)$ & 8.32 \\
\hline
\end{tabular}

Note: Invasive species in each successional group are denoted by “"'. Within each successional group, means having the same letter are not significantly different at $p=0.05$

Table 5 shows that except for Swietenia, all the other invasive species in the gap species group, had significantly greater LK than the standard species, Angiopteris. Similar to the pioneer species, the gap species are also exposed to high light levels during part of the day. Therefore, as explained earlier, a higher LK content would give a competitive advantage to a species in this group as well. However, it could be noted that, as in the case of leaf nitrogen, Swietenia macrophylla is an exception to the above general trend. This indicates that even within one successional group, more than one factor and different mechanisms could induce invasive behaviour.

\section{CONCLUSION}

The present study showed evidence that the invasive behaviour of the studied plant species could be a result of their possessing some key physiological characteristics which give them a competitive advantage in their functioning over the other species in the community. These include higher photosynthetic rates under both sunny and 
shaded conditions, higher stomatal resistances and higher leaf nitrogen contents for invasive species in all successional groups. In addition, a higher leaf potassium content could be responsible for the invasive behaviour among the early-successional and gap species.

\section{Acknowledgement}

We gratefully acknowledge the support of the officials of the Forest Department in charge of the Udawattakelle forest reserve.

\section{Reference}

1 Senadheera S.A.S.K. (1997). Classification and Analysis of Vegetation in Udawattakelle. B.Sc. Dissertation, Department of Crop Science, Faculty of Agriculture, University of Peradeniya.

2 Hitinayake H.M.G.S.B. \& Wedathanthri H.P. (1999). Invasive behaviour of Myroxylon balsamum of Udawattakelle forest reserve. Proceedings of the Annual Forestry Symposium: Challenges in Natural Resource Conservation in $21^{\text {st }}$ Century. Department of Forestry and Environmental Science, University of Sri Jayewardenapura, 10-11 December, 1999.

3 Panabokke C.R. (1996). Soils and Agro-ecological Environments of Sri Lanka. Natural Resources, Energy and Science Authority of Sri Lanka, Colombo.

4 Bazzaz F.A. \& Wayne P.M. (1994). Coping with environmental heterogeneity: The physiological ecology of tree seedling regeneration across the gapunderstorey continuum. In: Exploitation of Environmental Heterogeneity by Plants. (Eds. M.M. Caldwell \& R.W. Pearcy). pp. 349-390. Academic Press, California.

5 Chazdon R.L. \& Fetcher N. (1984). Photosynthetic light environments in a lowland tropical rain forest in Costa Rica. Journal of Ecology 72: 553-564.

6 Hesse P.R. (1971). A Textbook of Soil Chemical Analysis. John Murray, London.

$7 \quad$ Davidescu D. \& Davidescu V. (1982). Evaluation of Fertility by Plant and Soil Analysis. Abacus Press, UK.

8 Little T.M. \& Hills F.J. (1978). Agricultural Experimentation: Design and Analysis. John Wiley and Sons, New York.

9 Bazzaz F.A. (1979). Physiological ecology of plant succession. Annual Review of Ecology and Systematics 10: 351-371. 
10 Landsberg J.J. (1986). Physiological Ecology of Forest Production. Academic Press, London.

11 Pearcy R.W. (1990). Sunflecks and photosyr.thesis in plant canopies. Annual Review of Plant Physiology and Plant Molecular Biology 41: 421-453.

12 Chazdon R.L. (1988). Sunflecks and their importance to forest understorey plants. Advances in Ecological Research 18: 1-63.

13. Jarvis P.G. \& Leverenz J.W. (1983). Productivity of temperate, deciduous and evergreen forests. In Encyclopaedia of Plant Physiology, Vol. 12D. Physiological Plant Ecology IV. Ecosystem Processes: Mineral cycling, Productivity and Man's Influence. (Eds. O.L. Lange, P.S. Nobel, C.B. Osmond \& H. Ziegler). pp. 233280. Springer Verlag, Berlin.

14 Mooney H.A. (1972). The carbon balance of plants. Annual Review of Ecological Systems 3: 315-346.

15 Bazzaz F.A. (1991). Regeneration of tropical forests: physiological responses of pioneer and secondary species. In: Rain Forest Regeneration and Management. (Eds. A. Gomez-Pompa, T.C. Whitmore \& M. Hadley). pp. 91118. UNESCO/Parthenon, Paris/New Jersey.

16 Bazzaz F.A. (1996). Plants in Changing Environments. Cambridge University Press, Cambridge, UK.

17 Farquhar G.D. \& Sharkey T.D. (1982). Stomatal conductance and photosynthesis. Annual Review of Plant Physiology 33: 317-345.

18 Jones H.G. (1976). Crop characteristics and the ratio between assimilation and transpiration. Journal of Applied Ecology 13: 605-622.

19 Ludlow M.M. \& Muchow R.C. (1990). A critical evaluation of traits for improving crop yields in water-limited environments. Advances in Agronomy 43: 107-153.

20 Jarvis P.G. \& Morrison J.I.L. (1981). The control of transpiration and photosynthesis by the stomata. In: Stomatal Physiology. (Eds. P.G. Jarvis \& T.A. Mansfield). pp. 247-279. Cambridge University Press, Cambridge.

21 Burton P.J. \& Bazzaz F.A. (1995). Ecophysiological responses of tree seedlings invading different patches of old-field vegetation. Journal of Ecology 83: 99-112. 
22 Evans J.R. (1989). Photosynthesis and nitrogen relationships in leaves of $\mathrm{C}_{3}$ plants. Oecologia 78: 9-19.

23 Field C. \& Mooney H.A. (1986). The photosynthesis-nitrogen relationship in wild plants. pp. 25-55. In: On the Economy of Form and Function. (Ed. T.J. Givnish). pp. 25-55. Cambridge University Press, Cambridge.

24 Loomis R.S. \& Connor D.J. (1992). Crop Ecology: Productivity and Management in Agricultural Systems. Cambridge University Press, Cambridge.

25 Schmitt M.R. \& Edwards G.E. (1981). Photosynthetic capacity and nitrogen use efficiency of maize, wheat and rice: A comparison between $\mathrm{C}_{3}$ and $\mathrm{C}_{4}$ photosynthesis. Journal of Experimental Botany 32: 459-466.

26 Boardman N.K. (1977). Photosynthesis of sun and shade plants. Annual Review of Plant Physiology 28: 355-377.

27 Hsiao T.C., Hageman R.H. \& Tyner E.H. (1970). Effect of potassium nutrition on protein and free amino acids in Zea mays. Crop Science 10: 78-82.

28 Wildes R.A. \& Pitman M.G. (1975). Pyruvic kinase activity in roots of barley seedlings in relation to salt status. Zeitschrift fur Pflanzenphysiologie 76: 6975.

29 Hawker J.S., Marschner H. \& Krauss A. (1979). Starch synthesis in developing potato tubers. Physiologia Plantarum 46: 25-30.

30 Smid A.E. \& Peaslee E.E. (1976). Growth and $\mathrm{CO}_{2}$ assimilation by corn as related to potassium nutrition and simulated canopy shading. Agronomy Journal 68: 904-908.

:31 Leigh R.A. \& Wyn Jones R.G. (1984). A hypothesis relating critical potassium concentration for growth to the distribution and functions of this ion in the plant cell. New Phytologist 97: 1-13.

32 Wyn Jones, R.G., Storey R., Leigh R.A., Ahmad N. \& Pollard A. (1977). A hypothesis on cytoplasmic osmoregulation. In: Regulation of Cell Membrane Activities in Plants. (Ed. E. Marre \& O. Cifferi). pp. 121-136. Elsevier/North Holland Biomedical Press, Amsterdam.

33 Hsiao T.C. \& Lauchli A. (1986). Role of potassium in plant-water relations. In: Advances in Plant Nutrition, (Eds. B. Tinker and A. Lauchli). 2: 281-311. Praeger, New York. 